\title{
Is Women's Increased Accessibility to Land a Path to Sustainable Development? The Case of Urban Maseru, Lesotho
}

\author{
Keneuoe Anacletta Mots'oene \\ National University of Lesotho, Lesotho \\ k_motsoene@yahoo.co.uk
}

\begin{abstract}
This study argues that unlike other parts of Africa where women are marginalized and excluded from accessing resources particularly land, women in Lesotho have been empowered through the Act that gives them access to land which had not been the case in the in the past decades. This has made women potential agents in driving the process of sustainable development in the urban echelon of Maseru. The specific objective of this study therefore is to show that women in Lesotho are important catalysts in the sustainable development of Maseru, the capital city of Lesotho. This has increased their ability not only to use land for settlement but also engaged in economic activities that contribute to Lesotho's sustainable development. The study focused on three urban communities (Ha Foso, Sekamaneng, and Ha Matala) in Maseru. Purposeful sampling was engaged in selecting 80 female-headed households. It was discovered that women had both ownership and user rights of the land they occupied in their own capacity as household heads. The study has six sections: introduction, study objective, rationale, methodology, conceptual framework, study findings, conclusion.
\end{abstract}

Keywords: Sustainable development, female-headed households, land, ownership, user rights, customary

\section{Introduction}

Most studies across Africa show that kinship relationships embedded in customary laws influence women's access to land. This particularly affected the performance of women in engaging in only subsistence production rather than productive activities to generate more economic benefits for a better life. However, new developments have emerged where countries like Lesotho have began recognizing women as potential agents of sustainable development both in their households and the economy by giving them ownership and control over land in their own capacity whether married or not married. Today women in Lesotho are participating in the economy as entrepreneurs using land allocated to them. This indicates a reduction in marginalization and exclusion of women in accessing resources in the country which previously they had limited access to, an indication towards sustainable development. This paper intends to show this dilemma and suggests that this could be a good example for other countries to follow.

Study objective: The study aims at showing the increased access to and control over land by women living the urban areas of Maseru, the rapidly growing capital city of Lesotho, which has increased their capability towards sustainable development of the country. Such an insight I believe will inform other countries, particularly those in Africa about this development. As UN Economic and Social Council Commission on the status of women states that "land rights discrimination is a violation of human rights" (UN Habitat, 1999, p.1) Lesotho has moved a step forward in promoting the rights of women in securing land for their households' development. This has not enabled women to have food security only but also has promoted sustainable socio-economic development of such households and the country as women engage in other productive investments on such land. The study further aims at enhancing women's more access and control over land and the use of such land for sustainable development.

Rationale: Until recently, Maseru has not featured in the fast-growing literature on urban Africa, mainly because the literature does not regard it as a significant urban settlement. Most studies on the developmental challenges of Lesotho have focused on problems of rural areas (Murray, 1981; Wallis and Van de Geer, 1982; Sechaba Consultants, 1994 and Turner, 2003). As elsewhere in the developing world, the problem of women's access and control over land in Lesotho was a rural phenomenon. Maseru, being the primary city of Lesotho which is experiencing rapid population growth, has experienced this dilemma in a particularly form where, women are increasingly accessing and controlling land in their own capacity whether married or living in single female headed households. The relative absence of research 
in Maseru particularly in these areas means there is an endless list of unanswered questions. This research makes a modest contribution to this relatively new area of research by addressing aspects of gender equality focusing on women, and thus fills the gap in the literature on Maseru, making it a new contribution to the literature on small cities in Africa and on Lesotho in particular.

\section{Methodology}

Data presented in the study were obtained through primary data collection where interviews were carried out and secondary data collection by reviewing the existing literature on women's access to and control over land in sub-Saharan Africa and Lesotho. Interviews were used to obtain greater insight into women's perceptions on their access to and control over land and to assess both their past and current development. The study focused on three urban communities of Ha Foso, Sekamaneng and Ha Matala in Maseru. Purposeful sampling was engaged in selecting 80 women-headed households. Purposeful sampling allows the selection of areas and respondents suitable for obtaining needed information (see Neuman, 1997 and McMillan and Schumacher, 2001). The sample comprised subjects with needed characteristics indicating women's access and ownership of land.

\section{Conceptual Framework}

Women's empowerment and sustainable development: Sustainable development is about continued development of human life. Oxfam believes that all people have the right to an equitable share in the world's resources and to be active in their own development and that the denial of such rights is the heart of poverty and suffering. As such strengthening people's capacity to determine their own values and priorities and to act on their own, is the basis for sustainable development (Eade and Williams, 1995, p.9). This notion suggests that human capacity building is an important approach to sustainable development which identifies constraints women and men experience in realizing their basic right and find appropriate ways through which to strengthen their ability to overcome the causes of their exclusion and suffering. Development is about women and men being empowered to bring positive changes in their lives. It is about personal growth together with public action of challenging poverty, oppression and discrimination. It is about the realization of human potential, and a process of transforming lives and societies (Eade and Williams, 1995, p.9-10). This paper articulates on these debates to show the importance of empowering women so that they can realize their full potential in changing their lives and societies in which they live for sustainable development.

Women's access to and control over land: Experiences in sub-Saharan Africa: Land tenure systems are dominated by customary regimes across sub-Saharan Africa. Women have little or no means of claiming land or of inheriting property. This is more visible in patrilineal societies where women only access land through their male relatives on their husband's sides. Even in cases of matrilineal inheritance, men still seem to acquire land over women. Women's relationship with land is therefore through husbands, fathers, brothers or sons. Another ensuing problem restricting women's access to landis when a woman loses rights to land following the death of the husband. This involves the land of the deceased male being taken from the wife by male relatives of the deceased's family. This practice is largely accepted in customary regimes across the region, further increasing female insecurity and threatening household livelihoods (Chingarande, 2010 and http://www.wikigender.org/index.php/Women\% 27s_Access_to_Land_in_sub-Saharan_Africa\#Customary_regimes) and sustainable development.

Women, in particular widows and women-headed households, tend to be denied or are assigned weaker land rights and as a result are often amongst the most vulnerable people in society. Strengthening their rights to land contributes not only to gender equality but also to poverty reduction and sustainable development, since women are responsible for household subsistence production and welfare. IFAD's experience shows that improving women's economic status is essential for overall improvement in their social status and well-being, but for women's economic status to improve, they need secure access to land. Under customary law, women tend to have weaker but nonetheless protected rights. These rights tend to be eroded in rapidly changing societies. The main challenge is in managing the transition in a way that strengthens/defends the rights of women (IFAD, 2014). Some key legal provisions for strengthening women's rights could include the recognition of their "secondary" rights as being equal to men's rights, the co-registration of spousal rights and the recognition of women's inheritance rights. IFAD has learned that defending and expanding women's rights requires comprehensive action at different levels: information and capacity building; organizational and empowerment measures; legal assistance and 
advocacy. Land tenure issues are inextricably linked to gender relations and thus a gender analysis is critical to design effective, targeted actions. It is often necessary to put complementary measures in place to enable women to influence decisions about their rights to land (IFAD, 2014).

The right of women to own property, including land, is recognized under international human rights law. UN Economic and Social Council Commission on the status of women actually state that "land rights discrimination is a violation of human rights" (UN Habitat, 1999.1). Yet, women's property rights are limited by social norms and customs and at times by legislature in many countries (Clark, 2010). Most countries still lack adequate provisions for women to acquire land rights independently of their husbands or male relatives. Their legislation's statutory law do not provide for women's independent rights so women's direct access to land through purchase or inheritance is often limited. Other cultures have had similar traditional laws (Kalabamu, 1998). Women are seen just as mere household producers and are mostly customarily given indirect access to land in terms of these rights acquired through kinship relationships and their status as wives, mothers, sisters and daughters.

In recent years, international bodies have recognized the threats posed by the limited access to land for women in sub-Saharan Africa. Various NGOs are now very active in the region on the question of women's land rights. For example, the recent adoption by the South African Development Community of a Gender and Development Protocol in 2008. It recognizes that women have unequal legal status, including in relation to property rights and calls on states to review and reform all laws and policies that determine access to and control of resources, including land. It explicitly recommends that states protect widows from property grabbing (Chingarande, 2010). However, many governments have come up with policies supporting improved access to land by women but the implementation of such policies is almost nonexistent because it is slow. On the other hand, women's groups are working very hard but many of them have not been able to mobilize the broad section of society to support the idea of women's land rights. Land is the most important asset for many households in developing countries, particularly poor households. Land ownership confers direct economic benefits as a source of production and income, and as collateral for financial and credit services. This in return has multiplier effects on women's household welfare and the economy as a whole through poverty reduction (Clark, 2010) leading to sustainable development. This paper shows the position of Lesotho, with reference to urban communities in Maseru, the capital city of Lesotho.

Land tenure rights and women in Lesotho: Historical experience: Historically, Sotho society was predominantly patriarchal, with men controlling the homesteads, a phenomenon observed by Casalis (1861 in Thabane, 2002:179) nearly 150 years ago, "The father, the elder son and in some tribes, the maternal uncle, governed and protected the family". Following this view Mothibe, Pule and Thabane (2002) more recently explained that men owned both cattle and agricultural produce; they were responsible for clearing of land for agriculture, cattle-keeping, building of huts, making clothes from animal skins and were the ones called upon to defend and protect society when the need arose. Gill (1993) agrees with Mothibe et al (2002) by pointing out that together with time spent in decision-making process- khotla (public place for meetings), men contributed to the prosperity of body politic by providing resources such as manpower, knowledge and skills. Women were dependent on men legally, socially and economically. For example, women were regarded as minors and were denied the right to attend public meetings (lipitso) and to participate in decision-making processes. In fact women could only raise their concerns via male intermediaries, denying them an independent voice in the decision-making bodies thus reinforced their subordination to men. Yet, women played an important role in the agricultural economy that contributed to the wealth men controlled. They cultivated, sowed and weeded the fields in addition to the reproductive roles of being bearers of children and care-givers to the entire family members making women's work the main contributor to the sustenance and reproduction of the homestead (Gill, 1993 and Mothibe et al, 2002). This means that women remained subservient in the process of development throughout the pre-colonial, colonial to the late twentieth century.

Given the fact that Basotho have often been described as an agricultural society and $80 \%$ of its population was rural in the past, land was regarded as a source of livelihood and life revolved around land to a greater extent. Here land was the source of food, pasture for animals and the bearer of materials needed for production of handicrafts. The ability of the Basotho to retain land was linked to their political independence. Wars fought and treaties signed with the foreigners on the question of land were with the understanding that land belongs to Basotho. The commonly used phrase to describe the land tenure system was- the king holds land in trust of the whole nation. However, this pretext has never been clear in 
terms of ownership, right to access and the extent of such rights. This lack of clarity of who owns the land in Lesotho had a number of consequences (Thabane, 1998).

The period following the Lesotho's independence was characterized by grievances from the commoners complaining about the chiefs' abuse of their administration of land. These complaints included the chiefs' arbitrary refusal to allocate land and withdrawal of lands given to widows and old destitute women. Again this was the period when international financial institutions' missions were sent to investigate the land tenure system in Lesotho. They concluded that the land tenure in Lesotho did not give potential agents of economic development a security of tenure and needed to be changed to allow economic development and foreign investments. The post-colonial government then enacted laws aimed at addressing these issues. These laws were aimed at decentralizing power and decision-making on land to the local level. They included the Land Procedure Act of 1967, the Land Husbandry Act 1969 and the Land Act 1973 which introduced the lease system giving the government greater control over land particularly urban areas. These developments regarding access to land, did not consider women as potential development agents towards sustainable development by increasing their access to land. Women remained minors with only user rights from their spouses who were custodians of land whom the king had entrusted his powers in the protection and use of such land.

New efforts to increase women's access to land: Notwithstanding, the government of Lesotho subscribes to international protocols on women's empowerment such as the South African Development Community of a Gender and Development Protocol of 2008. In 2006, the Equal Married Persons Act was passed by the parliament of Lesotho and increased women's access to assets including land in their own right. This is not just an upgrading of women from their minor status but also an empowerment for sustainable development of the country. They can now engage in various productive activities to generate income and improve household welfare. Women are also found in the upper echelon of the business sector of the economy like men.

\section{Findings and discussion}

Women's access to land: Women in Maseru held tenure rights which included communal and freehold (See Table 1). The majority of them had full user rights to the land. About $50 \%$ in Ha Foso owned land in their capacity as women- heads of households, $10 \%$ in Sekamaneng, and $40 \%$ in Ha Matala (Field Survey, 2014). Sekamaneng had lower number mainly because this is a peri-urban community which was rural in the past. This area has recently been classified as urban, thus has fewer women who have secured land in their own capacity as heads. Ha Foso community had a larger number of women owning land. This is because it is a peri-urban community which was rural in the past that has recently attracted many immigrants from the countryside. Nonetheless, the situation differs from other countries in sub-Saharan Africa where women only have rights to use the land and real rights are located elsewhere within their patriarchal lineage. This is a positive transition towards sustainable development in urban Maseru.

Table 1: Women's access and control over land in urban communities of Maseru

\begin{tabular}{ll}
\hline Urban community & \% of ownership \\
\hline Ha Foso & 50 \\
Sekamaneng & 10 \\
Ha Matala & 40 \\
Total & 100 \\
\hline
\end{tabular}

Source: Field Survey, 2014

Land and women empowerment: In the three areas visited women were using their land in different ways. Evidence revealed that they used land for settlement as well as productive investments. About 50 $\%$ of women in Ha Foso engaged in poultry farming. They reared chicken for commercial purposes. In the Sekamaneng area, $6 \%$ of women who owned land planted vegetables for sale, while $2 \%$ engaged in petty trade in their yards selling small items including matches, sweets and snacks. Only $1 \%$ engaged in poultry farming for commercial purposes. In Ha Matala area, about $25 \%$ of women interview edalsoengaged in poultry farming for commercial purposes, $10 \%$ was engaged in piggery, selling both piglets and pig meat, $3 \%$ had cafes and 2\% owned guesthouses (Field Survey, 2014) (Table 2). This evidence suggests that women in Maseru who owned land are empowered to engage in productive investments which generate sustainable income for their households. The income from these activities had multiplier effects on both their households' welfare and the country. At the household level, these women were paying for their 
children's education. Some women had bought transport vehicles for carrying school-going children around the city to increase the level of household income and these women were drivers themselves. They are able to pay for their households' medical expenses. They mostly lived a decent urban life with electricity supply. These developmental activities indicate a positive socio-economic change in the household welfare and the country in that the level of poverty has declined indicating a change towards sustainable development.

Table 1: Women's economic activities in urban communities of Maseru

\begin{tabular}{llccccc}
\hline $\begin{array}{l}\text { Urban } \\
\text { Community }\end{array}$ & $\begin{array}{l}\text { Economic activity (\%) } \\
\text { Poultry }\end{array}$ & Piggery & Café & guesthouse & $\begin{array}{c}\text { Petty } \\
\text { trade }\end{array}$ & Vegetables \\
\hline $\begin{array}{l}\text { Ha Foso } \\
\text { Sekamaneng }\end{array}$ & 50 & & & & 2 & 6 \\
Ha Matala & 25 & 10 & 3 & 2 & & \\
\hline
\end{tabular}

Source: Field Survey, 2014

\section{Conclusion}

Women's access to and control over land in Maseru has empowered women to undertake income generating activities that were men's activities in the past. This gender equality has increased women's capability to improve their socio-economic status within society like men, a path towards sustainable development. Some of the productive activities like cafes and guesthouses were men's activities in the past. Women can now work independently from men as men appreciate the importance for women to access land and have control over land. Women have engaged in activities which have positively changed their households' welfare. However, like in any African patriarchal society some men still show some discomfort with this new development of allowing women to access land in their own right without their consent, particularly those living with spouses yet the law clearly allows women ownership right. The extent to which this affects such women is another area for future research. Notwithstanding, the government and other non-governmental development agencies still have to educate the society about women and land rights to further increase women's opportunities for sustainable development. Ensuring that women do enjoy full legal rights to own property and to inherit it is critical for economic empowerment and sustainable development. In order for women to have economic opportunity like access to credit and other financial services, they need to have the right to own and inherit property like land (Calvey, 2014 and IFAD, 2014).

\section{References}

Calvey, S. (2010). Women must be sensitized and empowered, in order to claim their rights to land in Women's Empowerment in Africa: Access to land, Credit, and Markets. Retrieved from http://www.undp.org/continent/undp/en/home/presscenter/speeches/20/10/07/02/womens -empowerment-in-africa-and=the-idcs.html.Retrieved on13 August 2014.

Clark, H. (2010). Introductory remarks on Economic Opportunities for the Empowerment of Women in Africa and the Least Developed Countries: Access to Land, Credit, and Markets. Retrieved from http://www.undp.org/continent/undp/en/home/presscenter/speeches/20/10/07/02/womens -empowerment-in-africa-and=the-idcs.html.Retrieved on13 August 2014.

Chingarande, S. D. (2010). Women in Africa and the Least Developed Countries: Access to Land, Credit, and $\quad$ Markets. Retrieved from http://www.undp.org/continent/undp/en/home/presscenter/speeches/20/10/07/02/womens -empowerment-in-africa-and=the-idcs.html.Retrieved on13 August 2014.

Eade, D and Williams, S. (1995). The Oxfam Handbook of Development. Oxford: Oxfam.

Gill, D. (1994). The Situation of Children and Women in Lesotho. Maseru: UNICEF and Government of Lesotho. http://www.wikigender.org/index.php/Women\%27s_Access_to_Land_in_subSaharan_Africa\#Customary_regimes.Retrieved on 1 August 2014.

International Fund for Agricultural development. (2014). Women's Access to land in sub-Saharan Africa. Retrieved from http://www.ifad.org/english/land/perspectives/gltn/women_FactSheet.pdf

Kalabamu, F. (1998). Effects of gendered land rights on urban housing by woman in Botswana: international conference and workshop on land tenure in Botswana, Gaborone.

Lesotho Government. Equal Married Persons Act 2006. Maseru: Government Printing.

Lesotho Government Land Act 1973. Maseru: Government Printing. 
Lesotho Government Land Husbandry Act 1969. Maseru: Government Printing.

Lesotho Government Land Procedure Act of 1967. Maseru: Government Printing.

McMillan, J. H. \& Schumacher, S. (2001). Research in Education. A conceptual Introduction. USA: Addison Wesley Longman.

Mothibe, T., Pule, N. W. \& Thabane, M. (2002). Essays on Aspects of the Political Economy of Lesotho 1500-2000. Morija: Morija Printing Works

Murray, C. (1981). Families divided: The Impact of Migrant Labor in Lesotho. South Africa: Ravan Press.

Neuman, L. (1997). Social Research Methods: Qualitative and Quantitative Approaches. London: Allyn and Bacon.

Sechaba Consultants. (1994). Poverty in Lesotho: A Mapping Exercise. Government of Lesotho Working Document. Maseru: Sechaba Consultants.

Thabane, M. (1998). Who Owns The Land in Lesotho? Land Disputes and The Politics of Land Ownership in Lesotho. Research Report No. 29. National University of Lesotho: Institute of African Studies.

Thabane, M. (2002). Colonial Economy and Society. In Pule, N.W. and Thabane, M., eds. Essays on Aspects of the Political Economy of Lesotho 1500 - 2000. Morija: Morija Printing Works

Turner, S. D. (2003). The Southern African Food Crisis: Lesotho Literature Review. Maseru: CARE Lesotho.

UN Habitat. (1999). Women's rights to land, housing and property in post-conflict situations and during reconstruction: UN Centre for Human Settlements, Nairobi, Kenya.

UN Habitat. (1999). Women's rights to land, housing and property in post-conflict situations and during reconstruction: UN Centre for Human Settlements, Nairobi, Kenya.

Wallis, M. \& van de Geer, R. (1982). Government and Development in Lesotho. Morija: Morija Printing Works. 